\title{
Study Regarding the Efficacy of Unconventional Treatment Products Against the Main Wheat Kernels Pathogens
}

\author{
Raluca MICLEA, Loredana SUCIU, Carmen PUIA* \\ Department of Environmental and Plant Protection, University of Agricultural Sciences and Veterinary \\ Medicine, Cluj-Napoca, Romania \\ *corresponding author, e-mail: carmen.puia@yahoo.com
}

Bulletin USAMV series Agriculture 74(2)/2017

Print ISSN 1843-5246; Electronic ISSN 1843-5386

DOI 10.15835/buasvmcn-agr: 0028

\begin{abstract}
The raising of agriculture to European Union standards requires adaptation of agricultural production to quality standards that meet the demands and exigencies of consumers by obtaining healthy crops that fit into the rigors of food security. The biological material used was constituted of wheat kernels from three varieties cultivated at ARDS Turda. The biological control of wheat pathogens can be successfully achieved, in vitro, with plant extracts, and the maximum effect of this bioproducts was achieved in the case of the variants treated with, tee tree essential oil, garlic, arnica, Hypericum perforatum and propolis.
\end{abstract}

Keywords: biocontrol, kernels, pathogens, unconventional

INTRODUCTION. In the culture of straw cereals, in order to increase the productivity it is necessary to use a healthy biological material (Barrett et al., 2010) with a high cultural value and a high degree of biological purity (Reeves et al., 2016). In an attempt to facilitate the conversion of traditional agriculture to organic farming and obtaining biological products, the experiments conducted in this research had the purpose of realizing and testing new unconventional products that will ensure effective control of both the major toxigenic fungi and fungi that influence the qualitative parameters of wheat kernels.

AIMS AND OBJECTIVES. The general objective of the present work was the identification of the main pathogens developed on different wheat varieties kernels and also the effect of unconventional treatment against these pathogens. The specific objectives were the study of the morphological and cultural characteristics of thee microflora isolated from wheat kernels, the growth rate of each pathogens culture in vitro, the form, dimension, aspect, colour of the colonies and the form, type, colour of mycelial hyphae, testing the effect of plant extracts against the pathogens identified.

MATERIALS AND METHODS. The biological material used was three varieties of wheat kernels cultivated at ARDS Turda, namely Dumbrava, Andrada and Arieșan. The microflora developed on them was analyzed and isolated on culture media. The research methods conducted in the experiments were the isolation of the pathogens form the vegetal material (wheat kernels), the growth of the pathogens in pure culture on media, in vitro, the observations on the phenotypic characteristics of the pathogens, microscopic observation on the pathogens for their identification. Also for the unconventional control of these pathogens identified, the biological material utilized was 16 hidroalcoolic plant extracts, 2 essential oils (Azadirachta indica and Melaleuca alternifolia) and also the propolis extract. The method for testing the efficiency 

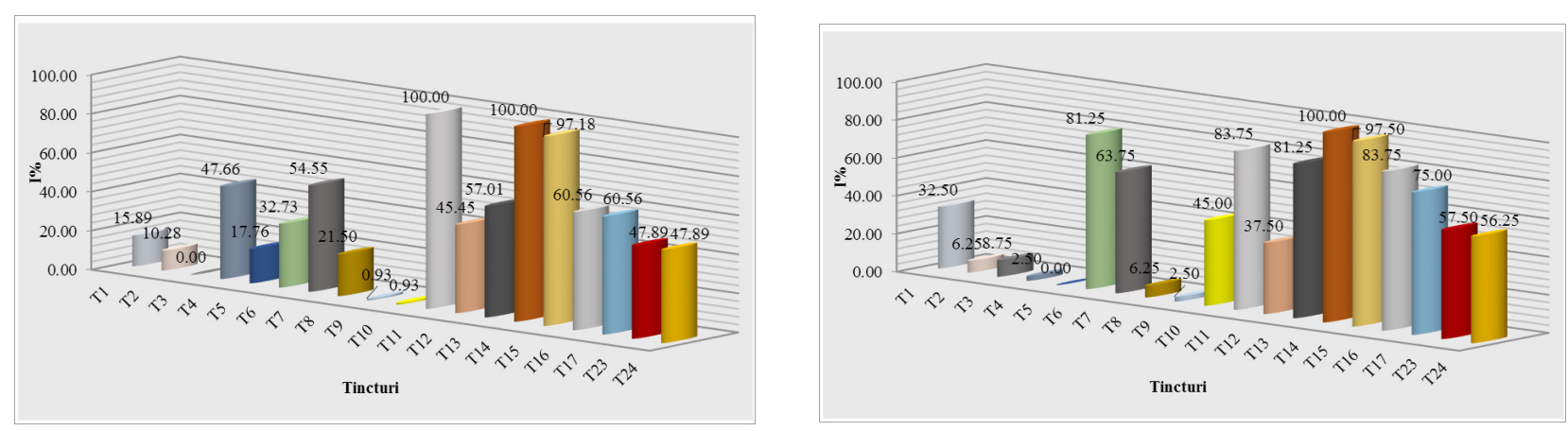

Fig. 1. The effect of the extract against Alternaria spp. And Fusarium spp. (inhibition \%) T1- Tagetes erecta and Tagetes patula, T2 - Satureja hortensis, T3 - Aristolochia clematitis, T4 Armoracia rusticana, T5 - Helleborus purpurascens, T6 - Picea sp., T7 - Arnica montana, T8 - Zingiber officinale, T9 - Allium cepa, T10 - Aloe. vera, T11 - Allium sativum, T12 - Hypericum perforatum, T13 - Azadirachta indica, T14 - Melaleuca alternifolia, T15- propolis, T16- Aloe marlothi, T17 - Aloe paradisiacum, T23 - Rubus idaeus, T24 - Achillea millefolium)

of the extracts was the poison food technique (Ndyri and Babu, 2005). The extracts were tested a concentration of $80 \mu \mathrm{l} / \mathrm{ml}$ and the observations regarding the growth of the colonies on media treated whit extracts were made for 9 days after the inoculation. The percent of inhibition was calculated for each extract after the formula: Inhibition percent $=(\mathrm{C}-\mathrm{T} / \mathrm{C}) \times 100$, where $\mathrm{C}$ represents the control colony and $\mathrm{T}$ represents the diameter of the colony grown on the treated medium (Ndyri and Babu, 2005).

RESULTS AND DISCUSSIONS. From the three wheat varieties kernels the pathogens identified and isolated were the pathogens Alternaria triticina and Alternaria tennuis, Aspergillus spp., Penicillium spp., Fusarium spp.

The extracts used in the experiment had different effect on the pathogens, at a concentration of $8 \%$, at 9 days after the in vitro inoculation, namely:

- The development of Alternaria spp. was completely inhibited, in a percent of $100 \%$, by the garlic and tee tree extracts and in a $97,18 \%$ by the propolis extract

- The propolis extract and the tee tree essential oil totally inhibited the development of the Aspergillus spp, followed at a $25 \%$ difference by the arnica extract, garlic and Hypericum perforatum hidroalcoolic extracts the percent of inhibition calculated was over $75 \%$

- The Penicillium spp. were inhibited completely by the tee tree essential oil, $80 \%$ inhibited by the propolis extract and $70 \%$ by Aloe paradisiacum extract

- Against the Fusarium spp. pathogen the highest inhibition percent was observed in the case of the colonies treated with tee tree essential oil, where the inhibition was total $(100 \%)$, followed by the propolis extract with a $97,5 \%$ and the Picea sp., garlic, Aloe paradisiacum, A. marlotii and neem extract with a percentage higher than $75 \%$.

CONCLUSION. In the present research work, we demonstrated that the biological control of wheat pathogens can be successfully achieved, in vitro, with plant extracts, and the maximum effect of this bioproducts was observed in the case of the variants treated with tee tree essential oil and garlic, arnica, Hypericum perforatum, propolis hidroalcoolic extract.

Acknowledgment: This paper was done through the Partnerships in priority areas - PN II program, developed with the MEN - UEFISCDI support, project no. PN-II-PT-PCCA-3013-4-1857.

\section{REFERENCES}

1. Barrett CB, Carter MR, Timmer CP (2010). A CenturyLong Perspective on Agricultural Development. American Journal of Agricultural Economics 92 (2):447 - 468.

2. Nidiry ESJ, Babu CSB (2005). Antifungal activity of tuberose absolute and some of its constituents. Phytother. Res. 19:447-449.

3. Reeves TG, Graeme T, Ramsay G (2016). Save and Grow in practice maize, rice, wheat. Food and Agriculture Organization of the United Nations Rome, A Guide to Sustainable Cereal Production. 